\title{
Indicators for the prescription of foot and ankle orthoses for children with Charcot-Marie-Tooth disease
}

\author{
Grant Scheffers $^{1 *}$, Claire Hiller ${ }^{1}$, Kathryn Refshauge ${ }^{1}$, Joshua Burns ${ }^{1,2}$ \\ From 3rd Congress of the International Foot and Ankle Biomechanics Community \\ Sydney, Australia. 11-13 April 2012
}

\section{Background}

Charcot-Marie-Tooth disease (CMT) is the most common inherited peripheral neuropathy and is associated with foot deformity, gait abnormalities and functional impairment. Orthoses are often prescribed for children with CMT, yet the indication and type of prescription is usually based on clinical judgement due to the lack of high quality research in this field. Therefore, the aims of this paper were to review the indications of commonly prescribed foot and ankle orthoses, and formulate a clinical algorithm for the optimal prescription of foot and ankle orthoses for children with CMT.

\section{Materials and methods}

We searched MEDLINE (from January 1966), EMBASE (from January 1980), CINAHL (from January 1982), AMED (from January 1985), Cochrane Neuromuscular Disease Group Specialized Register, and reference lists of articles.

\section{Results}

Table 1 shows a clinical algorithm for prescribing foot and ankle orthoses for children with CMT. In general, in-shoe orthoses are indicated for affected children with pes cavus deformity, foot pain and/or mild balance impairments. Ankle-foot orthoses are indicated for children with pes cavus, foot drop, foot and ankle muscle weakness and/or ankle equinus, and moderate-severe balance impairments and/or difficulty walking (selfreported clumsy gait, frequent trips/falls) and gait abnormalities (slower speed, shorter step length, wider base of support).
Table 1 Clinical algorithm for prescribing foot and ankle orthoses for children with CMT

\begin{tabular}{|c|c|}
\hline Impairments and activity limitations & Orthoses \\
\hline Pes cavus and foot pain & Foot orthoses \\
\hline Pes cavus and poor balance & UCBL* orthoses \\
\hline $\begin{array}{l}\text { Pes cavus and poorer balance (not corrected by } \\
\text { UCBL* orthoses) }\end{array}$ & $\begin{array}{l}\text { Supramalleolar } \\
\text { orthoses }\end{array}$ \\
\hline $\begin{array}{l}\text { Pes cavus and poorer balance (not corrected by } \\
\text { supramalleolar AFOst) }\end{array}$ & Hinged AFOst \\
\hline Foot drop and poor walking & $\begin{array}{l}\text { Posterior leaf spring } \\
\text { AFOst }\end{array}$ \\
\hline $\begin{array}{l}\text { Foot drop, poor walking, pes cavus, and poor } \\
\text { balance }\end{array}$ & $\begin{array}{l}\text { Hinged AFOst with } \\
\text { PF‡ stops }\end{array}$ \\
\hline Global weakness of foot/ankle muscles and poor & Hemispiral AFOst \\
\hline
\end{tabular}
walking and/or balance (with/without pes cavus and/or foot drop)

Global weakness of foot/ankle muscles and poorer walking and/or balance (not corrected by hemispiral AFOst, with/without pes cavus and/or foot drop)

Pes cavus and/or ankle equinus $\left(\geq 0^{\circ}\right.$, not corrected by hinged AFOst with/without PFł stops)

\section{Solid AFOst}

Solid AFOst

* University of California Biomechanics Laboratory; † ankle-foot orthoses; ₹ plantarflexion

\section{Conclusions}

A clinical algorithm is proposed to guide the prescription of orthoses for children with CMT. Further research is required to determine the efficacy of different foot and ankle orthoses, and the predictive ability of the proposed clinical algorithm to improve foot deformity, gait abnormalities and disability in childhood CMT.

\footnotetext{
* Correspondence: gsch8875@uni.sydney.edu.au

${ }^{1}$ Faculty of Health Sciences, The University of Sydney, NSW, Australia

Full list of author information is available at the end of the article
} 


\section{Author details}

${ }^{1}$ Faculty of Health Sciences, The University of Sydney, NSW, Australia.

${ }^{2}$ Institute for Neuroscience and Muscle Research, Children's Hospital at

Westmead, Sydney, Australia.

Published: 10 April 2012

doi:10.1186/1757-1146-5-S1-P23

Cite this article as: Scheffers et al.: Indicators for the prescription of foot and ankle orthoses for children with Charcot-Marie-Tooth disease.

Journal of Foot and Ankle Research 2012 5(Suppl 1):P23.

Submit your next manuscript to BioMed Central and take full advantage of:

- Convenient online submission

- Thorough peer review

- No space constraints or color figure charges

- Immediate publication on acceptance

- Inclusion in PubMed, CAS, Scopus and Google Scholar

- Research which is freely available for redistribution

Submit your manuscript at www.biomedcentral.com/submit
() Biomed Central 